Article

\title{
Could Defatted Mealworm (Tenebrio molitor) and Mealworm Oil Be Used as Food Ingredients?
}

\author{
Yang-Ju Son ${ }^{1,2}$, Soo Young Choi ${ }^{3}$, In-Kyeong Hwang ${ }^{2}$, Chu Won Nho ${ }^{1}$ and Soo Hee Kim ${ }^{4, *}$ \\ 1 Natural Products Research Institute, Korea Institute of Science and Technology, Gangneung Institute of \\ Natural Products, Gangneung, Gangwon-do 25451, Korea; yangjuson@kist.re.kr (Y.-J.S.); \\ cwnho1423@kist.re.kr (C.W.N.) \\ 2 Department of Food and Nutrition and Research Institute of Human Ecology, Seoul National University, \\ Seoul 08826, Korea; ikhwang@snu.ac.kr \\ 3 Sempio, Seoul 04557, Korea; drd0603542@naver.com \\ 4 Department of Culinary Arts, Kyungmin University, Uijeongbu, Gyeonggi-do 11618, Korea \\ * Correspondence: kshee@kyungmin.ac.kr; Tel.: +82-31-828-7271; Fax: +82-31-828-7951
}

Received: 8 December 2019; Accepted: 27 December 2019; Published: 2 January 2020

\begin{abstract}
Before edible insects may be used as an alternative food, it is necessary to develop basic product forms and evaluate their characteristics. We made two basic commercial products (defatted powder and oil) from mealworm, a popular edible insect. The defatted mealworm powder possessed a sufficient amount of protein, and it had a savory taste due to plentiful free amino acids. Additionally, it had abundant minor nutrients and bioactive compounds. The physicochemical properties of mealworm oil were very similar to vegetable oil, and mealworm oil was also abundant in bioactive nutrients, especially $\gamma$-tocopherol. In addition, the predicted shelf life of mealworm oil was suitable for commercial use. Moreover, mealworm had high antioxidant and anti-inflammation activities, which may arise from functional peptides and glucosamine derivatives such as chitin and chitosan. In short, the defatted mealworm powder and mealworm oil could be successfully used as novel food ingredients.
\end{abstract}

Keywords: mealworm; edible insect; defatted powder; mealworm oil; characteristics

\section{Introduction}

Although people are apprehensive about consuming insects, edible insects are one of the most promising alternative protein sources. Historically, humans have consumed many types of insects across the globe. The earth has been undergoing environmental change, and one of the major causes of this has been the increase in consumption of meat from vertebrates. However, it is a challenge to replace all animal-based foods with vegetables because of the low content of proteins and limiting amino acids in plants. For this reason, vegetarians may be critically exposed to a paucity of particular vitamins and minerals. In comparison, insects possess sufficient amounts of protein, and their amino acid distribution is better than that of vegetative protein sources [1].

The mealworm (Tenebrio molitor L.) is an edible insect that has been popular in the animal feed industry, and mealworm-based feed products have been extensively used from pets to fish farms. Numerous studies have found that mealworm provides moderate nourishment and that there is no noxious effect of consumption [2-5]. Moreover, one of the important advantages of mealworm as a food source is that it is suitable for mass production. The mealworm is tolerant to various environmental conditions and does not require a large area for growth [6]. Additionally, the mealworm has good sensory characteristics. Their texture is crispy, and the mealworm has a savory taste that is very similar to dried shrimp. 
A major problem associated with edible insects is an aversion to consumption based on their appearance. Thus, when mealworms are used in the food industry as an ingredient, processing such as pulverization and extraction could be helpful. However, the mealworm is composed of almost $30 \%$ fat, and this exceedingly high fat content is troublesome during pulverization processes. The agglomeration of powders, known as caking, is facilitated by high fat content in powders, and this state gives rise to a decrease in powder flowability [7]. For this reason, the separation of protein-rich and oil-rich components could be a good approach for developing food items from mealworms, as is the case for soybean. Hence in this study, defatted mealworm powder, and mealworm oil as a byproduct, were separated and the nutrition value and physicochemical characteristics of each were examined.

The goal of this study was to suggest proper products from mealworm that can be used in the food industry and consumed by public. Considering the psychological hesitation to eat insects, pulverization process was applied for elimination of its appearance. The defatted powder and oil were selected as basic products because the high fat content of mealworms disturbed the powdering process and transport equipment commonly used in the food industry. For defining characteristics of defatted mealworm powders, nutritional values and physicochemical characteristics were determined.

\section{Materials and Methods}

All chemicals used in this study were purchased from Sigma-Aldrich (St. Louis, MO, USA), and live mealworms were purchased from a farm in Gyeonggi-do, Korea.

\subsection{Preparation of Mealworm Powder and Oil Samples}

Live mealworms were fasted for three days to empty their guts. Mealworms were washed with tap water three times and blanched in boiling water $(1: 5, w / w)$ for $3 \mathrm{~min}$. Blanched mealworms were kept on a colander for cooling and removing excess water. After $30 \mathrm{~min}$, the remaining water was removed with a paper towel. An industrial hot-air dryer (LH.FC-PO-150; Lab house, Pocheon, Korea) was used for drying mealworms $\left(12 \mathrm{~h}, 60^{\circ} \mathrm{C}\right)$. Then, dried mealworms were pulverized with a blender (HR-2860; Philips, Amsterdam, The Netherlands) until resulting powders could pass a 30-mesh sieve $(535 \mu \mathrm{m})$, and this powder was used as whole-fat mealworm powder (WF-M).

For extracting oils, fivefold n-hexane was added to WF-M, and the mixture was placed on a shaker (SI600R; Lab Companion, Daejeon, Korea) for $6 \mathrm{~h}$ at $170 \mathrm{rpm}$. The extracted liquids were filtered with a No. 1 filter paper (Whatman, Buckinghamshire, UK). After three repetitions of extraction, n-hexane was removed with an evaporator (RE111; Búchi, Flawil, Switzerland) at $34^{\circ} \mathrm{C}$. The remained n-hexane in oils were eliminated with nitrogen gas, and the supernatant was collected as mealworm oil after centrifugation for $10 \mathrm{~min}$ at $1350 \times \mathrm{g}$ (Combi-514R; Hanil Science Industrial, Daejeon, Korea). A picture of mealworm oil is shown in Figure S1. The unsaponifiable lipid was made from mealworm oil by applying a saponification process, and its yield was $1.8 \% \pm 0.0 \%$.

After oil extraction, the powder remaining on the filter was collected. The defatted mealworm powder was put in a hood for $24 \mathrm{~h}$ at room temperature and further dried using a speed vacuum evaporator (Maxivac alpha; Labogene ApS, Lynge, Denmark) for $24 \mathrm{~h}$ at $40{ }^{\circ} \mathrm{C}$. The pressure was adjusted to under $7 \mathrm{mmHg}$, and its rotation speed was $2000 \mathrm{rpm}$. Finally, the powder was ground once more with a blender (HR-2860; Philips, The Netherlands) until it could pass through a 42-mesh sieve $(355 \mu \mathrm{m})$, and it was defatted the mealworm powder (DF-M) sample. The mealworm protein isolate (MPI) was produced from DF-M using the method of Sharma and Singh [8]. First, $20 \mathrm{~g}$ of DF-M was mixed with $200 \mathrm{~mL}$ of deionized water, and the $\mathrm{pH}$ was adjusted to $\mathrm{pH} 12$ with adding $1 \mathrm{~N}$ $\mathrm{NaOH}$. After shaking for $1 \mathrm{~h}$ at $220 \mathrm{rpm}$ (SI600R; Lab Companion, Korea), the solution was centrifuged for $20 \mathrm{~min}$ at $2000 \times g$ (Combi-514R; Hanil Science Industrial, Korea). The supernatant was collected, and the $\mathrm{pH}$ of solution was adjusted for 4.5 using $1 \mathrm{~N} \mathrm{HCl}$. After centrifuging for $20 \mathrm{~min}$ at $2000 \times g$ once more, liquid part was eliminated, and residue was collected only. The MPI was prepared by lyophilizing the residue. The yield of MPI was $13.0 \% \pm 0.3 \%$ and the crude protein content of MPI was $91.1 \% \pm 1.1 \%$. Pictures of mealworm powder samples are presented in Figure S2. 
The $80 \%$ methanol extract was obtained from DF-M. $40 \mathrm{~g}$ of DF-M was put into a flask, and $80 \%$ methanol solution $(1: 10, w / v)$ was added. At room temperature, the flask was placed in a shaker (SI600R; Lab Companion, Korea) for $12 \mathrm{~h}$ at $200 \mathrm{rpm}$. The solvent was filtered with a No.1 filter paper (Whatman, UK) and remaining powders were extracted twice more. Collected solvents were evaporated with an evaporator (RE111; Búchi, Switzerland), and the extraction yield was $15.5 \% \pm 0.6 \%$.

\subsection{Proximate Compositions and Amino Acid Compositions}

AOAC methods were used for determining moisture, crude fat, crude protein, and ash contents [9]. The carbohydrate content was calculated based on the sum of other contents. For analyzing the amino acids compositions, $0.5 \mathrm{~g}$ of mealworm powder was put in a flask and $20 \mathrm{~mL}$ of $6 \mathrm{~N}$ $\mathrm{HCl}$ was added, heated to $110{ }^{\circ} \mathrm{C}$, and incubated for $24 \mathrm{~h}$. The total volume of the solution was adjusted to $25 \mathrm{~mL}$ with distilled water after filtering. For derivatization of amino acids, borate buffer, o-phthaldialdehyde/2-mercaptopropionic acid, and fluorenylmethyloxycarbonyl chloride were mixed just before HPLC injection. The reversed-phase HPLC system (Ultimate 3000; Thermoscientific Dionex, MA, USA) was used for analyzing the content of amino acids, and the analysis conditions are shown in Table S1 [10].

\subsection{Protein Solubility}

The protein solubility of mealworm powder was determined with little modifications using the methods of Morr et al. [11] Distilled water was added to mealworm powder (1:10, w/v), and $\mathrm{pH}$ was adjusted to a range of $2-12$ with $1 \mathrm{~N} \mathrm{NaOH}$ and $1 \mathrm{~N} \mathrm{HCl}$. After centrifuging for $20 \mathrm{~min}$ at $2000 \times \mathrm{g}$ (Combi-514R; Hanil Science Industrial, Korea), the supernatant was collected. The Bradford method was used for measuring the amount of protein in the supernatant, and the protein solubility at each $\mathrm{pH}$ was compared with the protein solubility at $\mathrm{pH} 12$, the maximum point of protein solubility.

\subsection{Gel Permeation Chromatograph Analysis}

Gel permeation chromatography (GPC) was used to observe soluble particle size distributions. Mealworm powder samples were dissolved in $0.02 \mathrm{M} \mathrm{NaNO}_{3}(1: 10, w / v)$ for gathering hydrophilic particles, and the supernatant was collected by centrifugation $(2000 \times g, 20 \mathrm{~min})$. The GPC analysis was conducted with conditions as presented in Table S2. The soluble particle sizes were obtained by comparison with a calibration plot of log (molecular weight) versus retention time, created with polystyrene standards (Figure S3) [12].

\subsection{Fatty Acid Composition}

A total of $0.25 \mathrm{~g}$ of mealworm oil was mixed with $6 \mathrm{~mL}$ of $0.5 \mathrm{M}$ methanol sodium hydroxide, and heated using a water bath $\left(80^{\circ} \mathrm{C}, 10 \mathrm{~min}\right)$ for methylation of the oils. The mixtures were cooled on ice, and $7 \mathrm{~mL}$ of $14 \%$ boron trifluoride methanol solution was added, then the mixture was reheated $\left(80^{\circ} \mathrm{C}, 2 \mathrm{~min}\right)$. After cooling on ice, $5 \mathrm{~mL}$ of $\mathrm{n}$-hexane was added and the mixture was again heated $\left(80^{\circ} \mathrm{C}, 1 \mathrm{~min}\right)$. The top layer was collected and examined for fatty acid composition. Gas chromatography (GC) was used for analysis under conditions described in Table S3 [13].

\subsection{Physicochemical Properties of Mealworm Oil}

The specific gravity of mealworm oil was determined according to ASTM D1298 using a pycnometer. Specific gravity was calculated as the ratio of gravities between that of mealworm oil and distilled water at $15{ }^{\circ} \mathrm{C}$. The viscosity of mealworm oil at $20^{\circ} \mathrm{C}$ was measured with a Brookfield DV-IP viscometer (Brookfield, Middleboro, MA, USA) using spindle No. 62 at $60 \mathrm{rpm}$. Color values were measured with a colorimeter (CM-3500d; Minolta, Tokyo, Japan). A total of $4 \mathrm{~g}$ of mealworm oil was put to 35-mm petri dishes, and a light source was set to D65-10 ${ }^{\circ}$. The Hunter Lab colorimetric system was employed. The peroxide values and acid values were determined by the method of the Ministry of Food and 
Drug Safety of Korea [14]. The thiobarbituric acid reactive substances (TBARS) content in oil was measured using the method of Buege and Aust [15]. The induction time of oil was analyzed using rancimat 734 (Metrohm, Herisau, Switzerland). As described in the method of Gómez-Rico et al. [16], the measurement conditions were analogous to AFNOR NF EN ISO 6886. A total of $3 \mathrm{~g}$ of mealworm oil was put in a container, and oxidation was induced at $98^{\circ} \mathrm{C}$ under $20 \mathrm{~L} / \mathrm{h}$ air flow.

\subsection{Minor Nutrients in Mealworm Oil}

The contents of tocopherols in mealworm oil was measured using the method of Gliszczyńska-Świgło and Skiorska [17] with some modifications. First, $1 \mathrm{~g}$ of oil was dissolved in $5 \mathrm{~mL}$ of $\mathrm{n}$-hexane and filtered with a $0.2 \mu \mathrm{m}$ syringe filter. Reversed-phase HPLC was used with operation conditions as described in Table S4. For the determination of the content of polyphenol, $10 \mathrm{~g}$ of oil was dissolved in $50 \mathrm{~mL}$ of $\mathrm{n}$-hexane, and $20 \mathrm{~mL}$ of $60 \%$ methanol was added. After separating layers, the methanol fractions were collected and evaporated at $40{ }^{\circ} \mathrm{C}$. This condensed polyphenol residue was analyzed using the Folin-Ciocalteu method [18]. The content of squalene and sterols was analyzed in unsaponifiable lipid. The operating conditions for GC-MS are described in Table S5.

\subsection{Bioactive Nutrients of Mealworm Powder and Antioxidant Capacity}

$\gamma$-Aminobutyric acid (GABA) and taurine contents were analyzed using the same methods as amino acid composition analysis. Total glucosamine content was measured by the method of Belcher, Nutten, and Sambrook [19]. The content of polyphenol was determined by the Folin-Ciocalteu method [18], and the flavonoid content was measured by the method of Meda et al. [20] The polyphenol and flavonoid content was calculated with gallic acid equivalent (GAE) and catechin equivalent (CE) using standard curves, respectively. The antioxidant capacity of mealworm powder was confirmed by measuring DPPH radical scavenging activity and ABTS radical scavenging activity [21,22]. The antioxidant capacities of mealworm samples were compared with trolox standard, and were computed using trolox equivalent (TE).

\subsection{NO Reduction in Lipopolysaccharide-Induced RAW 264.7 Cell Line}

The murine macrophage cell line (RAW 264.7) was purchased from the American Type Culture Collection (ATCC, Rockville, MD, USA). The RAW 264.7 cells were seeded in a 96-well plate with a density of $5 \times 10^{4}$ cells per well. Then, $24 \mathrm{~h}$ after plating, the media was removed and cells were washed with PBS. The $80 \%$ methanol extract of DF-M and the unsaponifiable lipid of mealworm oil were added to cell cultures in various concentrations at $50 \mu \mathrm{L}$ per well. An hour later, the $50 \mu \mathrm{L}$ of media containing lipopolysaccharide (LPS) $\left(2 \mu \mathrm{g} \mathrm{mL}^{-1}\right)$ was added to each well. To analyze nitrite production, the supernatant of each well was collected after $24 \mathrm{~h}$ and mixed with Griess reagent at a 1:1 ratio. After 20 min, samples were analyzed with a microplate reader (SpectraMax 190, Molecular Devices, Sunnyvale, CA, USA) at $550 \mathrm{~nm}$. The concentration of nitric oxide was calculated by comparison with a sodium nitrite standard curve.

\subsection{Statistical Analysis}

All data are represented as the mean \pm standard deviation (SD). Measurements were performed in triplicate. One-way analysis of variance (ANOVA) and Duncan's multiple-range test $(p<0.05)$ were performed using the IBM SPSS statistics program, version 21.0 (IBM Inc., Armonk, NY, USA).

\section{Results and Discussion}

\subsection{Proximate Compositions and Amino Acid Compositions of Mealworm}

The mealworm is composed of high fat and high protein with low carbohydrate content (Table S6). The proximate composition of freeze dried WF-M is almost the same as that of Zhao et al. [23] The WF-M had $32.3 \% \pm 1.0 \%$ lipid content and this content is much higher than that found in soybean or 
meat $[24,25]$. When oils were extracted with $n$-hexane, DF-M had $70.8 \% \pm 5.8 \%$ protein content with $2.0 \% \pm 0.2 \%$ lipid content. Therefore, DF-M could be used as a protein rich food source.

The amino acid composition was calculated as a ratio to the crude protein amount (Table 1). The essential amino acid and non-essential amino acid ratio (E/NE) of mealworm was lower than meats such as chicken (0.75) and beef (0.7-0.8) [26,27]. Additionally, the content of branched amino acids (BCAA) was approximately $2 \%$ less than that of beef, eggs and chicken and accounts for $20 \%-22 \%$ of all amino acids $[26,27]$.

Table 1. Amino acids composition of whole-fat and defatted mealworm.

\begin{tabular}{|c|c|c|}
\hline & WF-M ${ }^{\dagger}$ & DF-M $\ddagger$ \\
\hline Protein (\%) & $52.2 \pm 0.6$ & $70.8 \pm 5.8$ \\
\hline \multicolumn{3}{|c|}{ Essential amino acids (g/100 g protein) } \\
\hline Histidine & $3.1 \pm 0.0$ & $2.9 \pm 0.2$ \\
\hline Lysine & $5.1 \pm 0.1$ & $5.1 \pm 0.4$ \\
\hline Methionine & $0.5 \pm 0.0$ & $1.2 \pm 0.1$ \\
\hline Phenylalanine & $3.9 \pm 0.0$ & $3.9 \pm 0.2$ \\
\hline Threonine & $4.8 \pm 0.0$ & $4.3 \pm 0.2$ \\
\hline Isoleucine & $4.5 \pm 0.0$ & $4.5 \pm 0.2$ \\
\hline Leucine & $7.5 \pm 0.0$ & $7.5 \pm 0.4$ \\
\hline Valine & $6.4 \pm 0.0$ & $6.4 \pm 0.4$ \\
\hline Sub total & $35.8 \pm 0.0$ & $35.6 \pm 0.3$ \\
\hline \multicolumn{3}{|c|}{ Non-essential amino acids (g/100 g protein) } \\
\hline Alanine & $8.1 \pm 0.0$ & $8.1 \pm 0.6$ \\
\hline Aspartic acid & $8.4 \pm 0.0$ & $8.4 \pm 0.4$ \\
\hline Arginine & $5.7 \pm 0.0$ & $5.7 \pm 0.3$ \\
\hline Cysteine & N.D. & N.D. \\
\hline Glutamic acid & $13.0 \pm 0.0$ & $13.2 \pm 0.5$ \\
\hline Glycine & $5.3 \pm 0.0$ & $5.3 \pm 0.4$ \\
\hline proline & $5.2 \pm 0.0$ & $5.4 \pm 0.4$ \\
\hline Serine & $4.8 \pm 0.0$ & $4.8 \pm 0.3$ \\
\hline Tyrosine & $7.3 \pm 0.0$ & $7.6 \pm 0.5$ \\
\hline Sub total & $57.7 \pm 0.0$ & $58.5 \pm 0.4$ \\
\hline Total $(\mathrm{E}+\mathrm{NE})^{\S}$ & $93.5 \pm 0.0$ & $94.1 \pm 0.4$ \\
\hline $\mathrm{E} / \mathrm{NE}$ & 62.0 & 60.9 \\
\hline CAA contents $(\%)^{\text {II }}$ & $19.4 \pm 0.0$ & $18.3 \pm 0.4$ \\
\hline
\end{tabular}

${ }^{\dagger}$ WF-M: Blanched and hot-air dried mealworm, ${ }^{\ddagger}$ DF-M: Defatted WF-M with solvent (n-hexane), ${ }^{\S}$ E: essential amino acids, NE: non-essential amino acids, ${ }^{\mathbb{I}}$ BCAA: branched amino acids.

The amino acid scores were calculated with the criteria of FAO/WHO [28] (Table 2). WF-M and DF-M both indicated methionine as a limiting amino acid. The DF-M presented a higher amino acid score than WF-M more than twice, and this may be caused by the difference in the loss-ratio for different types of amino acids. In the study of Jones et al. [29], there were two essential amino acids whose amino acid values were lower than the criteria, and these amino acids were same as those identified in this study (lysine and methionine). Jones et al. [29] said that the amino acid composition of mealworm could vary significantly depending on the mealworm feed, and lysine and methionine are known to be restricted amino acids in grains such as rice and soybean. Therefore, it is deemed necessary to increase the content of methionine in mealworm feed for better amino acid scores. 
Table 2. Essential amino acid amounts and amino acid scores of mealworm powders.

\begin{tabular}{cccc}
\hline & FAO/WHO Ref. (1985) & WF-M $^{\dagger}$ & DF-M ${ }^{\ddagger}$ \\
\hline Histidine & 20 & 30.7 & 28.9 \\
Lysine & 55 & 51.1 & 50.8 \\
Methionine + Cysteine & 35 & 5.1 & 11.5 \\
Phenylalanine + Tyrosine & 60 & 111.6 & 114.5 \\
Threonine & 40 & 47.9 & 43.3 \\
Isoleucine & 40 & 44.6 & 44.5 \\
Leucine & 70 & 65.4 & 74.5 \\
Valine & 50 & Met & Met \\
\hline Limiting amino acids & 14.6 & 32.9 \\
\hline Amino Acids Score (AAS)
\end{tabular}

\subsection{Protein Solubility and Soluble Particle Size Distributions of Mealworm Powders}

The protein solubility of DF-M and MPI over a range of $\mathrm{pH}$ conditions are shown in Figure S4. For DF-M, protein solubility was less than $30 \%$ at $\mathrm{pH} 7$ compared to $\mathrm{pH} 12$. It was expected that mealworm protein is mainly composed of hydrophobic rather than hydrophilic protein, which can cause increased turbidity in solution. Therefore, it was deemed that it would be necessary to modify or degrade mealworm protein to enhance its solubility in use. In comparison, the MPI sample had a rapid decrease in solubility only near the isoelectric point, $\mathrm{pH} 4-6$. Therefore, MPI appears to be a more suitable form for use in liquid foods.

Using gel permeation chromatography (GPC), the size distribution of soluble particles of DF-M and MPI were analyzed (Figure 1). The hydrophilic solutions of DF-M and MPI showed peaks at $117-118,308-311,958$, and $1450 \mathrm{Da}$. As the average molecular weight of amino acids is approximately $142 \mathrm{Da}$, peaks that matched single amino acids (117-118 Da) and peptides composed of two (308-311 $\mathrm{Da})$, seven $(958 \mathrm{Da})$, and 10 (1450 Da) amino acids were analyzed. The most conspicuous difference in peak areas between DF-M and MPI was the peak of 308-311 Da. In DF-M, the peak area of the protein fraction with a molecular weight of 308 Da was $42.6 \%$, but when protein was purified to MPI, the peak area of $311 \mathrm{Da}$ was reduced to $18.0 \%$. Therefore, it is assumed that a large number of particles in this range was lost during MPI refining.

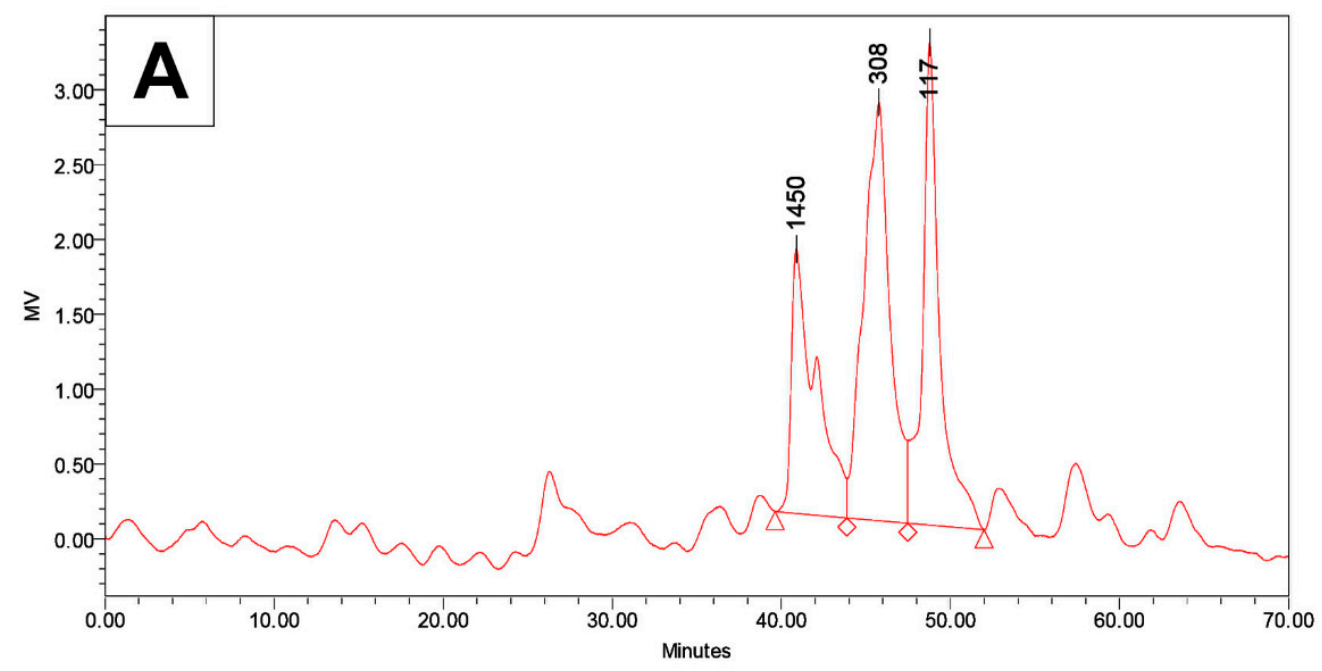

Figure 1. Cont. 


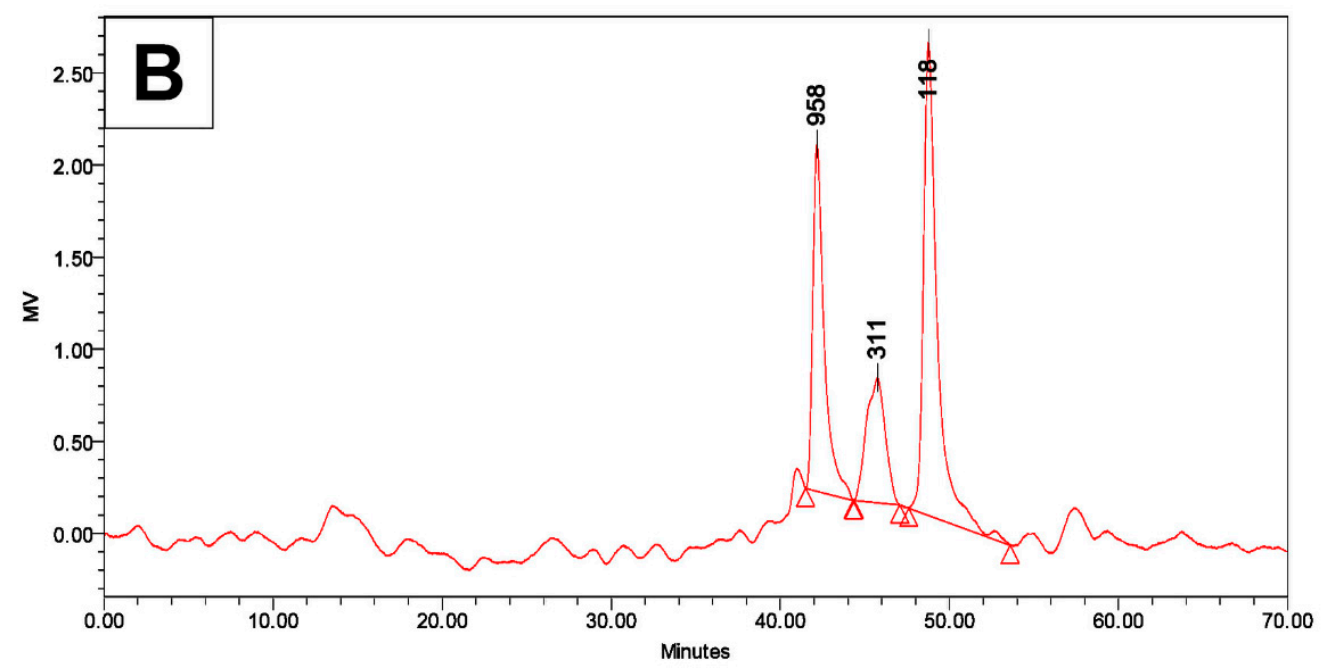

Figure 1. Size distribution of soluble particles of mealworm samples by gel permeation chromatography (GPC) analysis. (A) Defatted mealworm powder; (B) mealworm protein isolate.

\subsection{Fatty Acid Composition of Mealworm Oil}

Regarding the composition of fatty acids in mealworm oil (Table 3) oleic acid (44.5\% $\pm 1.1 \%$ ) was the most abundant fatty acid, and linoleic acid was the $(19.5 \% \pm 0.8 \%)$ second most abundant. The fatty acid composition results showed were very similar to study of Jeon et al. [13] about oil of roasted or unroasted mealworm oil. Animal lipids contain high levels of saturated fatty acids (SFA) compared to vegetable lipids. Mealworm, however, possessed a much higher amount of unsaturated fatty acid $(66.0 \% \pm 0.7 \%)$. The content of polyunsaturated fatty acid (PUFA) of mealworm $(19.8 \% \pm 0.9 \%)$ was also higher than pork (15.7\%), lamb (2.3\%), and beef (1.6\%) [30]. In comparison, mealworm oil had a much higher value $(47.0 \pm 4.6)$ for the ratio of $n-6$ fatty acids and $n-3$ fatty acids than typical animal lipids. The high ratio of n-6: n-3 is characteristic of vegetative oils, and the ratio for corn oil (31.9) was similar to that of mealworm oil [31]. Therefore, the composition of fatty acids in mealworm oil is believed to be much closer to the characteristics of vegetable oil.

Table 3. Fatty acid composition of mealworm oil.

\begin{tabular}{cc}
\hline Fatty Acids & Composition $(\mathbf{g} / \mathbf{1 0 0} \mathbf{g}$ oil) \\
\hline C4:0 & N.D. \\
C6:0 & N.D. \\
C8:0 $0: 0$ & N.D. \\
C10:0 $11: 0$ & N.D. \\
C12:0 & N.D. \\
C13:0 & $0.3 \pm 0.0$ \\
C14:0 $14: 1_{\text {cis }}$ & $0.1 \pm 0.0$ \\
C16:0 $16: 1_{\text {cis }}$ & $4.0 \pm 0.2$ \\
C17:0 & N.D. \\
C18:0 $18.8 \pm 0.1$ \\
C18: $1_{\text {cis }}$ & $1.8 \pm 0.1$ \\
C18:2 (n-6) & $0.1 \pm 0.0$ \\
C18:3 (n-3) & $2.3 \pm 0.2$ \\
C20:0 & $44.5 \pm 1.1$ \\
C20: $1_{\text {cis }}$ & $19.5 \pm 0.8$ \\
C20:2 (n-6) & $0.4 \pm 0.1$ \\
\hline
\end{tabular}


Table 3. Cont.

\begin{tabular}{cc}
\hline Fatty Acids & Composition $(\mathbf{g} / \mathbf{1 0 0}$ g oil) \\
\hline Total & $88.6 \pm 0.6$ \\
\hline SFA $^{\dagger}$ & $22.6 \pm 0.1$ \\
\hline MUFA $^{\ddagger}$ & $46.2 \pm 1.6$ \\
\hline PUFA $^{\S}$ & $19.8 \pm 0.9$ \\
\hline USFA $^{\text {I }}$ & $66.0 \pm 0.7$ \\
\hline n-6:n-3 ratio & $47.0 \pm 4.6$ \\
\hline P:S ratio & $0.9 \pm 0.0$ \\
\hline
\end{tabular}

Data are expressed as mean $\pm \mathrm{SD},{ }^{\dagger}$ SFA: Saturated fatty acid, $\ddagger$ MUFA: Monounsaturated fatty acid, $\S$ PUFA: Polyunsaturated fatty acid, II USFA: Unsaturated fatty acid.

\subsection{Physicochemical Properties and Minor Nutrients of Mealworm Oil}

The physicochemical properties and amounts of minor nutrients of mealworm oil are described in Table 4. Mealworm oil appeared as a light-yellow liquid, such as commonly used edible oils, with an extraction yield of $29.5 \% \pm 1.0 \%$. The peroxide value of mealworm oil was higher than those of commercialized edible oils, which were in the range of less than $2 \mathrm{meq} / 1000 \mathrm{~g}$ oil [31]. A previous study [13] of mealworm oil showed even higher peroxide values (4.98-9.94 meq/1000 $\mathrm{g}$ oil) than this study, suggesting that the high peroxide value of extracted oil may be a trait of the mealworm itself.

Table 4. Physicochemical properties and nutrient composition of mealworm oil.

\begin{tabular}{|c|c|}
\hline & Mealworm Oil \\
\hline Extraction Yield (\%) & $29.5 \pm 1.0$ \\
\hline Specific gravity $\left(15^{\circ} \mathrm{C}\right)$ & $0.8528 \pm 0.0032$ \\
\hline Viscosity $(\mathrm{cP})$ & $324.2 \pm 6.3$ \\
\hline \multicolumn{2}{|l|}{ Color } \\
\hline L (lightness) & $38.9 \pm 0.3$ \\
\hline a (redness) & $-1.9 \pm 0.1$ \\
\hline b (yellowness) & $7.5 \pm 0.6$ \\
\hline Peroxide value (meq/1000 g oil) & $3.5 \pm 0.2$ \\
\hline Acid value (mg KOH/g oil) & $2.6 \pm 0.0$ \\
\hline TBARS (mg MDA/1000 g oil) & $1.8 \pm 0.1$ \\
\hline \multicolumn{2}{|c|}{ The contents of tocopherols (mg/1000 g oil) } \\
\hline$\alpha$-Tocopherol & $6.3 \pm 0.1$ \\
\hline$\beta$-Tocopherol & $8.5 \pm 0.6$ \\
\hline$\gamma$-Tocopherol & $123.5 \pm 2.7$ \\
\hline$\delta$-Tocopherol & $6.1 \pm 0.3$ \\
\hline Total tocopherol & $144.3 \pm 3.0$ \\
\hline Total polyphenol (mg GAE ${ }^{\dagger} / 1000$ g oil) & $18.0 \pm 1.3$ \\
\hline Squalene (mg/1000 g oil) & $21.1 \pm 5.0$ \\
\hline Induction time $(\mathrm{h})$ & $36.0 \pm 0.7$ \\
\hline Predicted shelf-life (day) $\ddagger$ & 305 \\
\hline
\end{tabular}

Data are expressed as mean $\pm \mathrm{SD},{ }^{\dagger} \mathrm{GAE}$ : Gallic acid equivalent, ${ }^{\ddagger}$ Shelf-life prediction at $20^{\circ} \mathrm{C}$ was calculated by $\mathrm{OSI}_{20} \times$ (factor of safety), $\mathrm{OSI}_{20}$ : induction time at $20^{\circ} \mathrm{C}$ (calculated by $\mathrm{Q}_{10}$ factor: 2.05), factor of safety: 0.7 .

Tocopherol (vitamin E) is one of the most important nutrients in lipids. It is a natural antioxidant that prevents free radical and hydroperoxy radical oxidation of lipids in fat-soluble foods, and it is synthesized in plants and algae [32]. In mealworm oil, the total tocopherol content was $144.3 \pm 3.0 \mathrm{mg} / 1000 \mathrm{~g}$ oil, and $\gamma$-tocopherol was the main type of tocopherol $(123.5 \pm 2.7 \mathrm{mg} / \mathrm{kg}$ 
oil), accounting for $85.6 \%$ of the total tocopherol. In regard to animal food sources, chicken and pork contained $2.7-4.2$ and $9.5-100 \mathrm{mg} / 1000 \mathrm{~g}$ oil total tocopherol, respectively [33,34]. In comparison, the total tocopherol amounts in olive and soybean oils are in the range of $80-1360 \mathrm{mg} / 1000 \mathrm{~g}$ oil [35], so the total tocopherol content of mealworm oil was lower than vegetable sources and higher than animal lipids. Polyphenols are also widely distributed in vegetable foods, and are known to have variable functionalities. The polyphenol content of mealworm oil was measured at $18.0 \pm 1.3 \mathrm{mg} / 1000 \mathrm{~g}$ oil. This value was $10 \%-20 \%$ of that in olive oil and grape seed oil (62-172 mg/1000 g oil) [16]. Some vegetable oils contain abundant phytosterols, such as stigmasterol and ergosterol, and these compounds have biological activities when ingested, but neither phytosterol was detected in mealworm oil of this study. Cholesterol is mainly contained in animal foods and is known to be associated with arteriosclerosis, increasing the concentration of lipid globules in the blood. When GC-MS was used for detection of cholesterol, the chromatogram for mealworm oil had extremely small peaks, therefore, we also failed to quantify this. Therefore, mealworm oil was much richer in minor nutrients than animal lipids, and its cholesterol amount was lower than the limit of quantitation and limit of detection (LOQ $\approx 2.6 \mathrm{ppm}, \mathrm{LOD} \approx 8.7 \mathrm{ppm}$ ).

The induction time of mealworm oil was measured by accelerating oxidation using a rancimat, and the commercial extra-virgin olive oil was used as control in this study. The induction time of mealworm oil was $36.0 \pm 0.7 \mathrm{~h}$, and it was lower than that of olive oil $(47.6 \pm 0.8 \mathrm{~h})$. A higher induction time indicates that they are less oxidized. In the study of Gómez-Rico et al. [16], the induction time of commercial olive oil was in the range of 30-60 h, and this value was similar with that obtained in this study. For the viability of mealworm oil as a commercial product, we predicted the shelf life of oil based on the induction time results. In the study of Farohoosh [36], they calculated Q10 values and the oil stability index (OSI20) that offers a prediction of shelf life of oils at $20^{\circ} \mathrm{C}$ based on the induction time. Under these conditions, the shelf life of olive oil in this study was forecasted to $404 \mathrm{~d}$. This value was similar with shelf life of commercial extra virgin olive oil. When using this forecast model, the estimated shelf life of mealworm oil at $20^{\circ} \mathrm{C}$ was $305 \mathrm{~d}$, which was approximately 10 months.

\subsection{Bioactive Nutrients, Antioxidant Capacity, and Anti-Inflammation Activity of Mealworms}

In Table 5 the bioactive nutrients in DF-M are presented. In general, the amount of taurine in animal food sources is higher than that in plants. For example, beef and pork have $40-60 \mathrm{mg} / 100 \mathrm{~g}$ [37]. Although the amount of taurine in mealworms was about half as much as that in beef or pork, the taurine content of DF-M $(17.8 \pm 0.3 \mathrm{mg} / 100 \mathrm{~g})$ was higher than that of plant sources. The mealworm is known to contain glucosamine derivatives in its skin, such as chitin and chitosan. Glucosamine is one of the natural amino sugars of the hexosamine family and it is a basic monomer of chitin (N-acetyl-D-glucosamine) and chitosan. Chitin and chitosan relieve degenerative arthritis by inhibiting inflammatory reactions in the joint region [38]. The total glucosamine content of DF-M was measured as $7.0 \% \pm 0.7 \%$.

Table 5. The $\gamma$-Aminobutyric acid (GABA), taurine, glucosamine, polyphenol, and flavonoid contents and radical scavenging activities of defatted mealworm.

\begin{tabular}{cc}
\hline & DF-M $^{+}$ \\
\hline GABA (mg/100 g dry basis) & $3.5 \pm 0.1$ \\
Taurine (mg/100 g dry basis) & $17.8 \pm 0.3$ \\
Glucosamine (g/100 g dry basis) & $7.0 \pm 0.7$ \\
Polyphenol (mg GAE $\ddagger / 100$ g dry basis) & $8.2 \pm 0.2$ \\
Flavonoid (mg CE $\$ / 100$ g dry basis) & $2.0 \pm 0.2$ \\
DPPH (mg TE $\mathbb{I} / g$ dry basis) & $21.5 \pm 0.5$ \\
ABTS (mg TE $\mathbb{T} / g$ dry basis) & $12.3 \pm 0.5$
\end{tabular}

Data are expressed as mean $\pm \mathrm{SD},{ }^{\dagger}$ DF-M: Defatted mealworm powder, ${ }^{\ddagger} \mathrm{GAE}$ : Gallic acid equivalent,,$\$ \mathrm{CE}$ : Catechin equivalent, II TE: Catechin equivalent. 
The content of polyphenols and flavonoids in DF-M were $8.2 \pm 0.2 \mathrm{mg} \mathrm{GAE} / 100 \mathrm{~g}$ and $2.0 \pm 0.2 \mathrm{mg}$ $\mathrm{CE} / 100 \mathrm{~g}$, respectively, and these amounts were lower than those of vegetables such as onions, tomatoes, and cabbage, and fruits such as cherries and plums (13-100 mg GAE/100 g) [39]. However, the DPPH and ABTS radical scavenging powers of mealworm extract were not much less than vegetable foods. Thus, it was thought that there are additional substances involved in antioxidant properties besides polyphenols and flavonoids. Many studies have shown that some peptides in protein foods have excellent antioxidant properties [40]. Therefore, it is expected that some specific peptides in mealworm also affect in its antioxidant capacity.

In addition, as shown in Figure 2, the NO production of LPS-induced RAW 264.7 cells were lowered by treatment with $80 \% \mathrm{MeOH}$ extract of DF-M $(25-500 \mu \mathrm{g} / \mathrm{mL})$ and unsaponifiable lipid $(0.05-5 \mu \mathrm{g} / \mathrm{mL})$. As suggested for antioxidant activities, functional peptides and glucosamine derivatives such as chitin and chitosan may strongly affect the anti-inflammation activity of mealworm extract $[38,41]$. Additionally, the unsaponifiable lipid of mealworm oil decreased NO production significantly, demonstrating that the lipid portion of mealworm could alleviate inflammation as well.
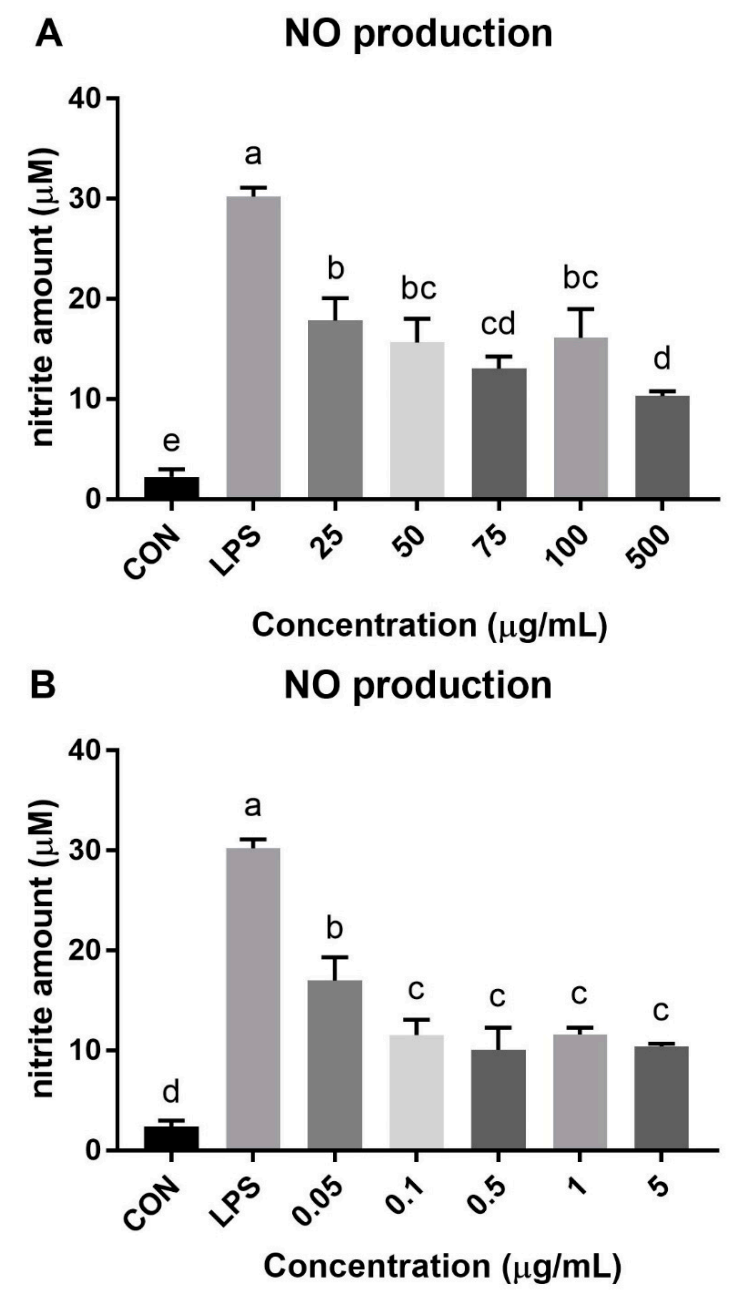

Figure 2. Reduce of NO production on lipopolysaccharide (LPS)-induced (1 $\mu \mathrm{g} / \mathrm{mL})$ RAW 264.7 cell line. (A) The $80 \%$ methanol extract of defatted mealworm powder; (B) unsaponifiable lipid of mealworm oil. Different superscripts (a-e) represent significant differences at $p<0.05$.

\section{Conclusions}

In this study, two basic types of products (defatted powder and oil) were prepared from whole fat mealworm, and both products were characterized for use as food ingredients. DF-M was light-brownish powder rich in protein $(70.8 \% \pm 5.8 \%)$. Methionine was a limiting amino acid of DF-M, and the 
proportion of lysine in DF-M was also lower than established criteria. Therefore, it would be necessary to increase methionine in mealworm feed in order to improve amino acid scores. Meanwhile, free amino acids were very abundant in DF-M, which could strongly affect the taste of mealworm products. The protein solubility in water was not great with DF-M, so some processing would be needed for preventing turbidity and precipitation. The refining of DF-M to MPI was able to enhance the protein solubility. For mealworm oil, oleic acid was the most abundant fatty acid, and the fatty acid composition of mealworm oil was very similar to vegetable oils. Mealworm oil contained plentiful tocopherols and other minor nutrients, but only trace levels of cholesterol. The predicted shelf life was almost 10 months. Therefore, mealworm oil has appropriate characteristics for general-purpose use. Moreover, the antioxidant capacity and anti-inflammation activity of DF-M extract were very high, likely as a result of abundant glucosamine derivatives and functional peptides. In short, defatted mealworm powder has adequate nutritional value and is rich in protein, minor nutrients, and bioactive compounds. Mealworm oil, a byproduct of DF-M, also had good nutritional value and characteristics for versatile use as a food ingredient. In addition, the DF-M and mealworm oil had antioxidant and anti-inflammation activities. Thus, mealworm could replace meat from vertebrates, but there was one limitation with respect to a specific amino acid, i.e., methionine.

Supplementary Materials: The following are available online at http://www.mdpi.com/2304-8158/9/1/40/s1, Figure S1: Pictures of mealworm oil extracted with n-hexane, Figure S2: Pictures and color values of whole- or defatted-mealworm powders and mealworm protein isolate (MPI), Figure S3: GPC calibration plot, Figure S4: Protein solubility of mealworm powder, Table S1: HPLC operating conditions for analyzing amino acid contents, Table S2: Operating conditions for GPC analysis, Table S3: GC analysis conditions for examining fatty acids composition, Table S4: Operating conditions of HPLC for analyzing tocopherol contents, Table S5: Analysis conditions of squalene and sterols by GC-MS analysis, Table S6: Proximate compositions of mealworm powders.

Author Contributions: The study was designed by Y.-J.S., I.-K.H. and S.H.K. Y.-J.S. and S.Y.C. conducted experiments and analyses of this study. Y.-J.S., S.Y.C. and C.W.N. organized figures and tables with data. The manuscript was written by Y.-J.S., I.-K.H., C.W.N. and S.H.K. All authors have read and agreed to the published version of the manuscript.

Funding: This work was supported by "Development of recipes and manufacturing technology for promoting the consumption of edible insects (Project No. 315060-3)" by the Ministry of Agriculture, Food and Rural Affairs, Republic of Korea.

Conflicts of Interest: The authors declare no conflict of interest.

\section{References}

1. Oonincx, D.G.A.B.; van Itterbeeck, J.; Heetkamp, M.J.W.; van den Brand, H.; van Loon, J.J.A. An exploration on greenhouse gas and ammonia production by insect species suitable for animal or human consumption. PLOS ONE 2010, 5, e14445. [CrossRef] [PubMed]

2. Li, L.Y.; Zhao, Z.R.; Liu, H. Feasibi lity of feeding yellow mealworm (Tenebrio molitor L.) in bioregenerative life support systems as a source of animal protein for humans. Acta Astronaut. 2013, 92, 103-109. [CrossRef]

3. Siemianowska, E.; Kosewska, A.; Aljewicaz, M.; Skibniewska, K.A.; Polak-Juszczak, L. Larvae of mealworm (Tenebrio molitor L.) as European novel food. Agric. Sci. 2013, 4, 287-291.

4. Han, S.R.; Lee, B.S.; Jung, K.J.; Yu, H.J.; Yun, E.Y.; Hwang, J.S.; Moon, K.S. Safety assessment of freeze-dried powdered Tenebrio molitor larvae (yellow mealworm) as novel food source: Evaluation of 90-day toxicity in Sprague-Dawley rats. Regul. Toxicol. Pharmacol. 2016, 77, 206-212. [CrossRef]

5. Ravazanaadii, N.; Kim, S.H.; Choi, W.H.; Hong, S.J.; Kim, N.J. Nutritional value of mealworm, Tenebrio molitor as food source. Int. J. Indus. Entomol. 2012, 25, 93-98. [CrossRef]

6. Makkar, P.S.H.; Tran, G.; Heuzé, V.; Ankers, P. State-of-the-art on use of insects as animal feed. Anim. Feed Sci. Technol. 2014, 197, 1-33. [CrossRef]

7. Foster, D.K.; Bronlund, E.J.; Paterson, T.A.H.J. The contribution of milk fat towards the caking of dairy powders. Int. Dairy J. 2005, 15, 85-91. [CrossRef]

8. Sharma, L.; Singh, C. Sesame protein based edible films: Development and characterization. Food Hydrocoll. 2016, 61, 139-147. [CrossRef] 
9. AOAC. Methods 932.06, 925.09, and 923.03. In Official Method of Analysis of AOAC International, 16th ed.; Association of Official Analytical Communities: Arlington, VA, USA, 1995.

10. Son, Y.J.; Lee, J.C.; Hwang, I.K.; Nho, C.W.; Kim, S.H. Physicochemical properties of mealworm (Tenebrio molitor) powders manufactured by different industrial processes. LWT-Food Sci. Technol. 2019, 116, 108514. [CrossRef]

11. Morr, C.V.; German, B.; Kinsella, J.E.; Regenstein, J.M.; van Buren, J.P.; Kilara, A.; Lewis, B.A.; Mangino, M.E. A collaborative study to develop a standardized food protein solubility procedure. J. Food. Sci. 1985, 50, 1715-1718. [CrossRef]

12. Grubisic, Z.; Rempp, P.; Benoit, H. A universal calibration for gel permeation chromatography. Polym. Lett. 1967, 5, 753-759. [CrossRef]

13. Jeon, Y.H.; Son, Y.J.; Kim, S.H.; Yun, E.Y.; Kang, H.J.; Hwang, I.K. Physicochemical properties and oxidative stabilities of mealworm (Tenebrio molitor) oils under different roasting conditions. Food Sci. Biotechnol. 2016, 25, 105-110. [CrossRef] [PubMed]

14. Ministry of Food and Drug Safety. Korean Food Standards Codex II; Ministry of Food and Drug Safety: Seoul, Korea, 2015; p. 48.

15. Buege, J.A.; Aust, S.D. Microsomal lipid peroxidation. Methods Enzymol. 1978, 52, 302-310. [PubMed]

16. Gómez-Rico, A.; Salvador, M.D.; Moriana, A.; Pérez, D.; Olmedilla, N.; Ribas, F.; Fregapane, G. Influence of different irrigation strategies in a traditional Cornicabra cv. olive orchard on virgin olive oil composition and quality. Food Chem. 2007, 100, 568-578. [CrossRef]

17. Gliszczyńska-Świgło, A.; Skiorska, E. Simple reversed-phase liquid chromatography method for determination of tocopherols in edible plant oils. J. Chromatogr. 1992, 1048, 1184-1188. [CrossRef]

18. Singleton, V.L.; Rossi, J.A. Colorimetry of total phenolics with phosphomolybdic-phosphotungstic acid reagents. Am. J. Enol. Viticult. 1965, 16, 144-158.

19. Belcher, R.; Nutten, A.J.; Sambrook, C.M. The determination of glucosamine. Analyst 1954, 79, $201-208$. [CrossRef]

20. Meda, A.; Lamien, C.E.; Romito, M.; Millogo, F.; Nacoulma, O.G. Determination of the total phenolic, flavonoid and proline content in Burkina Fasan honey, as well as their radical scavenging acitivity. Food Chem. 2005, 91, 571-577. [CrossRef]

21. Brand-Williams, W.; Cuvelier, M.E.; Berset, C. Use of a free radical method to evaluate antioxidant activity. LWT-Food Sci. Technol. 1995, 28, 25-30. [CrossRef]

22. Re, R.; Pellegrini, N.; Proteggente, A.; Pannala, A.; Yang, M.; Rice-Evans, C. Antioxidant activity applying an improved ABTS radical cation decolorization assay. Free Radic. Biol. Med. 1999, 26, 1231-1237. [CrossRef]

23. Zhao, X.; Vázquez-Gutiérrez, J.L.; Johansson, D.P.; Landberg, R.; Langton, M. Yellow mealworm protein for food purposes-Extraction and functional properties. PLoS ONE 2016, 11, e0147791. [CrossRef] [PubMed]

24. Friedrich, J.P.; List, G.R. Characterization of soybean oil extracted by supercritical carbon dioxide and hexane. J. Agric. Food Chem. 1982, 30, 192-193. [CrossRef]

25. Brewer, M.S. Reducing the fat content in ground beef without sacrificing quality: A review. Meat. Sci. 2012, 91, 385-395. [CrossRef] [PubMed]

26. Lee, K.C.; Lee, S.K.; Kim, H.K. Chemical compositions of the four lines of Korean native chickens. Korean J. Poult. Sci. 2016, 43, 119-128. [CrossRef]

27. Franco, D.; González, L.; Bispo, E.; Rodríguez, P.; Garabal, J.I.; Moreno, T. Study of hydrolyzed protein composition, free amino acid, and taurine content in different muscles of galician blonde beef. J. Muscle Foods 2010, 21, 769-784. [CrossRef]

28. FAO/WHO/UNU. Energy and Protein Requirements; World Health Organization Technical Report Series 724; FAO/WHO/UNU: Geneva, Switzerland, 1985.

29. Jones, L.D.; Cooper, R.W.; Harding, R.S. Composition of mealworm Tenebrio molitor larvae. J. Zoo Anim. Med. 1972, 3, 34-41. [CrossRef]

30. Enser, M.; Hallett, K.; Hewitt, B.; Fursey, G.A.J.; Wood, J.D. Fatty acid content and composition of English beef, lamb and pork at retail. Meat. Sci. 1996, 42, 443-456. [CrossRef]

31. Kamal-Eldin, A. Effect of fatty acids and tocopherols on the oxidative stability of vegetable oils. Eur. J. Lipid. Sci. Technol. 2006, 58, 1051-1061. [CrossRef]

32. Bramley, P.M.; Elmadfa, I.; Kafatos, A.; Kelly, F.J.; Manios, Y.; Roxborough, H.E.; Schuch, W.; Sheehy, P.J.A.; Wagner, K.H. Review: Vitamin E. J. Sci. Food Agric. 2000, 80, 913-938. [CrossRef] 
33. Maraschiello, C.; Sárraga, C.; Regueiro, J.A.G. Glutathione peroxidase activity, TBARS, and $\alpha$-tocopherol in meat from chickens fed different diets. J. Agric. Food Chem. 1999, 47, 867-872. [CrossRef]

34. Surai, P.F.; Sparks, N.H.C. Tissue-specific fatty acid and $\alpha$-tocopherol profiles in male chickens depending on dietary tuna oil and vitamin E provision. Poult. Sci. 2000, 70, 1132-1142. [CrossRef] [PubMed]

35. Okogeri, O.; Tasioula-Margari, M. Changes occurring in phenolic compounds and $\alpha$-tocopherol of virgin olive oil during storage. J. Agric. Food Chem. 2002, 50, 1077-1080. [CrossRef] [PubMed]

36. Farhoosh, R. The effect of operational parameters of the rancimat methods on the determination of the oxidative stability measures and shelf-life prediction of soybean oil. J. Am. Oil Chem. Soc. 2007, 84, 205-209. [CrossRef]

37. Lourenço, R.; Camilo, M.E. Taurine: A conditionally essential amino acid in humans? An overview in health and disease. Nutr. Hosp. 2002, 17, 262-270.

38. Largo, R.; Alvarez-Soria, M.A.; Díez-Ortego, I.; Calvo, E.; Sánchez-Pernaute, O.; Egido, J.;

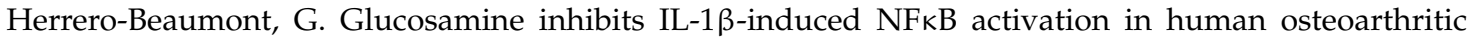
chondrocytes. Osteoarthr. Cartil. 2003, 11, 290-298. [CrossRef]

39. Bahorun, T.; Luximon-Ramma, A.; Crozier, A.; Aruoma, O. Total phenol, flavonoid, proanthocyanidin and vitamin C levels and antioxidant activities of Mauritian vegetables. J. Sci. Food Agric. 2004, 84, 1553-1561. [CrossRef]

40. Je, J.Y.; Park, P.J.; Kim, S.K. Antioxidant activity of a peptide isolated from Alaska pollack (Theragra chalcogramma) frame protein hydrolysate. Food Res. Int. 2005, 38, 45-50. [CrossRef]

41. Zielińska, E.; Baraniak, B.; Karaś, M. Identification of antioxidant and anti-inflammatory peptides obtained by simulated gastrointestinal digestion of three edible insects species (Gryllodes sigillatus, Tenebrio molitor, Schistocerca gragaria). Int. J. Food Sci. Technol. 2018, 53, 2542-2551. [CrossRef]

(C) 2020 by the authors. Licensee MDPI, Basel, Switzerland. This article is an open access article distributed under the terms and conditions of the Creative Commons Attribution (CC BY) license (http://creativecommons.org/licenses/by/4.0/). 